\title{
MELESTARIKAN BATIK TRADISIONAL RIFA'IYAH SEBAGAI IDENTITAS BUDAYA KOMUNITAS RIFA'IYAH
}

\author{
Sri Mustika \\ Fakultas Ilmu Sosial dan Ilmu Politik, Jurusan Ilmu Komunikasi, Universitas Muhammadiyah Prof. Dr. HAMKA \\ Jl. Limau II, Kebayoran Baru, Jakarta, 12130, Indonesia \\ No. Telp/Hp: 0217205218/087781684057 \\ E-mail: ikasdarma@yahoo.com
}

Naskah diterima pada tanggal 30 Januari 2018, direvisi tanggal 12 Mei 2018, disetujui tanggal 24 Mei 2018

\section{PRESERVING RIFA'IYAH BATIK AS CULTURAL IDENTITY OF RIFA'IYAH COMMUNITY}

\begin{abstract}
There are various types of batik in Indonesia. One of them is Rifa 'iyah batik produced by Rifa 'iyah community in Kalipucang Wetan, Batang, Central Java. It gets the strong influence of Islam. It is classical batik since the motifs persist from one generation to another generation. This research focuses on the preservation of batik as the cultural identity of Rifa'iyah community. By using the paradigm of constructivism, cultural identity theory, and methods of phenomenology, the researcher intends to understand the preservation effort of batik Rifa'iyah. Data were collected based on observation, in-depth interviews, and documentation study. Data analysis was done by coding system development technique. This study found that members of the batik Rifa'iyah community still admit batik as their cultural identity. But nowadays young batik artists have increasingly reduced, so it is feared that no one will preserve batik Rifa'iyah in the future. Various efforts to maintain it among others are by forming Rifa'iyah batik maker community serving as coordinating institution, organizing batik workshop for batik makers, attending batik exhibition, opening free batik class for elementary students, and motivating teenagers to appreciate batik as their cultural heritage.
\end{abstract}

Keywords: Rifa'iyah batik, Rifa'iyah community, culture identity.

\begin{abstract}
Abstrak. Di Indonesia terdapat berbagai macam jenis batik. Salah satu di antaranya adalah batik Rifa 'iyah yang dibuat oleh kaum perempuan Rifa'iyah di Desa Kalipucang Wetan, Batang, Jawa Tengah. Batik Rifa'iyah memperoleh pengaruh syariat Islam yang sangat kuat. Batik ini tergolong klasik karena motifnya dibuat sama dari satu generasi ke generasi berikutnya. Penelitian ini memfokuskan pada pelestarian batik Rifa'iyah sebagai identitas kultural komunitas. Dengan menggunakan paradigma konstruktivisme, teori identitas kultural, dan metode fenomenologi, peneliti bermaksud memahami upaya pelestarian batik yang dilakukan komunitas Rifa'iyah. Pengumpulan data dilakukan dengan pengamatan, wawancara mendalam, dan studi dokumentasi. Analisis data dilakukan dengan teknik pengembangan sistem koding, yaitu pengorganisasian data menurut tema konseptual yang dikenal peneliti. Kode berasal dari kisah informan, pertanyaan penelitian, dan kerangka teori. Peneliti menemukan bahwa anak-anak perempuan komunitas Rifa 'iyah tidak lagi tertarik untuk membatik sehingga dikhawatirkan akan mengancam kelestarian batik Rifa 'iyah. Berbagai strategi dilakukan untuk melestarikan batik ini, antara lain dengan membentuk Paguyuban Pembatik Rifa'iyah sebagai wadah para pembatik untuk saling bertukar informasi mengenai batik, mengadakan pelatihan membatik untuk meningkatkan kualitas mutu batik, mengikuti pameran batik, memberikan kursus membatik secara cuma-cuma kepada anak-anak, dan memotivasi para remaja untuk menekuni batik sebagai apresiasi pada warisan budaya.
\end{abstract}

Kata kunci: batik Rifa'iyah, komunitas Rifa'iyah, identitas kultural. 


\section{PENDAHULUAN}

Bangsa Indonesia terdiri atas berbagai etnik dan suku. Setiap etnik dan suku memiliki budaya sendiri. Menurut Geertz, kebudayaan merupakan pola makna yang secara historis ditransmisikan dan tersimpan di dalam simbol-simbol, sebuah sistem warisan konsepsi yang diekspresikan dalam bentuk simbol-simbol makna dan dengan hal itu manusia mengomunikasikan, mengabadikan, dan mengembangkan pengetahuan dan sikap mereka terhadap kehidupan (Geertz, 1992)

Simbol-simbol yang digunakan ini merupakan hasil kesepakatan bersama. Maknanya pun demikian. Simbol inilah yang kemudian menjadi tuntunan tingkah laku setiap anggota masyarakat atau komunitas. Budaya sebagai pola transmisi sejarah dari satu generasi ke generasi berikutnya dilakukan melalui simbol-simbol yang mereka gunakan. Gudykunst \& Kim (1999) melihat budaya sebagai sistem yang mengekspresikan konsep-konsep warisan budaya melalui simbol-simbol yang digunakan oleh anggota komunitas budaya tersebut ketika mereka berkomunikasi.

Menurut Ting Toomey dalam Samovar \& Porter (2007b), di antara beberapa fungsi budaya salah satunya adalah makna identitas. Budaya dianggap dapat memberikan kerangka rujukan untuk menjawab pertanyaan mengenai identitas diri seseorang yang sesungguhnya. Makna identitas yang didapat dari budaya dikonstruksikan dan dipelihara melalui komunikasi dalam kehidupan seharihari. Tanpa komunikasi budaya akan berhenti. Budaya menjadi bagian dari perilaku komunikasi dan pada gilirannya komunikasi pun ikut menentukan, mengembangkan, dan mewariskan budaya. Karena itu menurut Hall dalam (Mulyana, 2008), budaya adalah komunikasi dan komunikasi adalah budaya.

Budaya memiliki beberapa fungsi, seperti makna identitas, inklusi kelompok, regulasi keterikatan in-group dan out-group, adaptasi ekologis, dan komunikasi budaya (Rahardjo \& Ramadhan, 2005). Di antara fungsi-fungsi ini terdapat fungsi inklusi kelompok. Artinya, budaya dapat memuaskan kebutuhan seseorang terhadap afiliasi keanggotaan dan rasa ikut memiliki. Dalam konteks ini budaya dianggap dapat menciptakan inklusi, sehingga orang dapat memasukkan dirinya ke dalam kelompok tertentu sebagai in-group dan orang lain ke dalam out-group. Dengan memahami mana in-group dan out-group, orang akan membentuk sikap evaluatif terhadap interaksi in-group dan out-group.

Jika seseorang berafiliasi dengan suatu kelompok budaya tertentu, maka ia pun merasa memiliki identitas budaya tersebut. Identitas budaya yang terbentuk dalam kehidupan suatu masyarakat akan memengaruhi persepsi diri setiap anggota masyarakat. Bagaimana seseorang memandang dirinya, bersikap, dan bertingkah laku sangat dipengaruhi oleh identitas budayanya (Darmastuti, 2013). Identitas merupakan penghubung utama antara individu dengan masyarakat dan komunikasi menjadi mata rantai yang memungkinkan adanya hubungan ini. Dengan demikian komunikasi merupakan sarana terbentuknya identitas budaya seseorang.

Sejumlah warga yang bermukim di kawasan Kalipucang Kidul, Batang, Jawa Tengah mengidentifikasi diri mereka sebagai kelompok jamaah Rifa'iyah. Mereka adalah para pengikut Kiai Haji Ahmad Rifa'i, seorang ulama kelahiran Kendal, Jawa Tengah, pada awal abad 18, yang gigih melawan Belanda. Pada umumnya anggota komunitas Rifa'iyah yang laki-laki bekerja sebagai petani, sedangkan yang perempuan sebagai ibu rumah tangga dan membatik. Batik karya mereka oleh orang di luar komunitas dinamai sebagai batik Rifa'iyah.

Perbedaan batik Rifa 'iyah dengan batik lainnya terletak pada pakem atau aturan yang melarang untuk menggambar motif makhluk bernyawa secara utuh. Hal ini sejalan dengan syariat Islam yang melarang menggambar makhluk bernyawa. Siapa yang mengenakan batik dengan motif makhluk bernyawa kemudian dia salat, maka salatnya dianggap tidak sah. Salah satu motif batik Rifa'iyah yang berisi nilai Islam adalah batik pelo ati (ampela dan hati). Hati menggambarkan sifat- 
sifat kebaikan dan ampela melambangkan sifat-sifat keburukan.

Batik Rifa'iyah dibatik pada kedua sisi kainnya (bolak-balik). Warnanya terdiri atas dua warna atau yang disebut bangbiron (bang: merah dan biron: biru). Ada juga yang memiliki tiga warna (tiga negeri), yaitu merah, biru, dan cokelat. Pada zaman dahulu pewarnaan batik Rifa'iyah lebih banyak menggunakan tumbuh-tumbuhan yang banyak ditemukan di kawasan Batang. Misalnya, untuk memperoleh warna merah digunakan akar pohon mengkudu (javanoni), warna biru didapat dari tanaman nila, dan untuk mendapat warna cokelat digunakan daun alpukat. Kini para pembatik sudah menggunakan pewarna kimia karena lebih praktis.

Para pembatik biasanya memerlukan waktu selama satu-tiga bulan untuk membuat selembar kain batik tulis. Hal ini tergantung pada kerumitan motifnya. Bagi kebanyakan pengrajin batik Rifa'iyah, membatik merupakan pekerjaan sambilan. Karena itu mereka membatik tanpa target waktu. Mereka membatik setelah mengerjakan tugas rumah tangga, seperti memasak, mencuci, membereskan rumah, dan mengurus anak. Pada musim tanam padi atau panen, mereka meninggalkan semua kegiatan membatik, karena harus pergi ke sawah membantu suami.

Keterampilan membatik ini didapat secara turun-temurun dari ibu kepada anakanak perempuannya. Bagi perempuan Rifa'iyah, kain batik selain merupakan pakaian sehari-hari juga sekaligus penanda (identitas) komunitas. Dengan mengenakan batik Rifa'iyah ketika bepergian mereka akan mudah dikenali, baik oleh sesama anggota komunitas maupun oleh masyarakat umum. Selain sebagai identitas, batik Rifa'iyah juga berfungsi sebagai pengingat bagi para anggota komunitas agar memegang teguh ajaran-ajaran Islam yang mulia. Persoalannya sekarang, minat anak-anak perempuan muda Rifa'iyah terhadap batik berkurang. Hal ini berakibat pada menurunnya jumlah pembatik. Jika dulu pembatik mencapai 150 orang, kini menyusut menjadi 84 orang. Pembatik senior tinggal satu orang. Itu pun sudah berusia hampir 80 tahun.
Dari paparan di atas tampak bahwa komunitas Rifa'iyah mengalami persoalan dalam mempertahankan batik sebagai identitas budayanya. Penelitian ini mengkaji bagaimana upaya komunitas Rifa'iyah untuk melestarikan batik sebagai identitas budayanya. Penelitian ini bertujuan memahami upaya komunitas Rifa'iyah dalam melestarikan batik sebagai identitas budayanya.

Penelitian-penelitian mengenai identitas budaya telah banyak dilakukan peneliti terdahulu. Di antaranya penelitian yang dilakukan Indah Ella Susanti dan Sri Mastuti Purwaningsih pada tahun 2015. Mereka meneliti tentang Lumpia Semarang sebagai Identitas Budaya Etnik Tionghoa Peranakan Semarang. Pendekatan penelitiannya adalah kualitatif deskriptif. Tujuannya untuk mendeskripsikan perkembangan lumpia Semarang pada masa Orde Baru, mengidentifikasi makna lumpia sebagai identitas khas etnik Tionghoa peranakan Semarang. Peneliti menggunakan teori identitas budaya. Teknik pengumpulan data dilakukan dengan pengamatan, wawancara mendalam, dan studi pustaka (Susanti \& Purwaningsih, 2015).

Temuan penelitian menunjukkan bahwa etnik Tionghoa peranakan Semarang sebagai etnik minoritas mendapatkan perlakuan diskriminatif pada masa Orde Baru. Kendati demikian mereka tetap dapat mengembangkan perekonomian, khususnya perdagangan. Tak terkecuali dalam hal perdagangan makanan, seperti lumpia. Lumpia merupakan makanan hasil akulturasi etnik Tionghoa dengan penduduk setempat (Jawa Semarang). Lumpia memiliki makna sosial dan makna politik bagi etnik Tionghoa peranakan Semarang.

Penelitian lain dilakukan oleh Yudha (2014). Ia meneliti tentang Perubahan Identitas Budaya Etnik Tionghoa di Desa Pupuan, Kecamatan Pupuan, Kabupaten Tabanan. Penelitian ini bertujuan untuk melihat perubahan identitas etnik Tionghoa di Desa Pupuan, faktor-faktor yang memengaruhi perubahan identitas, dan implikasi serta makna perubahan identitas budaya mereka. Peneliti menggunakan paradigma kritis dan beberapa teori, seperti 
teori hibriditas, teori hegemoni, dan teori praktis. Pendekatan yang digunakan kualitatif. Teknik pengumpulan data dilakukan dengan observasi, wawancara mendalam, dan studi pustaka.

Temuan penelitian menunjukkan bahwa etnik Tionghoa berubah identitas budayanya. Hal ini ditandai dengan beralihnya agama dan kepercayaan, nama, dan bahasa mereka. Faktor yang memengaruhi adalah adanya kemiripan antara etnik Tionghoa dengan etnik Bali dalam hal nilai-nilai dan kepercayaan, faktor sosial dan ekonomi, serta tekanan dari pemerintah Indonesia. Implikasi perubahan identitas ini terjadi pada harmonisasi dan asimilasi budaya dan makna ekonomi.

Penelitian mengenai batik Rifa'iyah juga pernah dilakukan oleh Aquamila Bulan Prizilia (Prizilla \& Sachari, 2018). Prizilia meneliti tentang Perancangan Ragam Hias Batik Rifa'iyah. Ia meneliti khusus ragam hias pelo ati yang menjadi ciri khas batik Rifa'iyah. Peneliti menyimpulkan bahwa gambaran motif pelo ati dibuat berdasarkan ajaran Islam yang diajarkan oleh Syekh Ahmad Rifa'i. Kedua organ ayam ini menggambarkan sifat manusia yang terdiri atas baik dan buruk yang berakar pada hati manusia. Ajaran Kiai Rifa'i tentang sifat baik dan buruk manusia ada di dalam kitab Tarajumah.

Secara umum, ornamen motif-motif batik mengandung pesan yang ingin disampaikan oleh pembatik kepada pengguna batik. Sebelumnya, Soekma Yeni Astuti (Astuti, 2006) juga meneliti tentang batik Rifa'iyah dengan fokus pada Bentuk Ragam Hias Batik Rifa'iyah di Kalipucang Wetan, Batang. Peneliti yang menggunakan metode etnografi ini menemukan sekitar 24 motif batik Rifa 'iyah berikut makna-maknanya.

Penelitian ini berbeda dengan penelitian-penelitian sebelumnya, karena mengambil perspektif komunikasi dan berfokus pada upaya komunitas Rifa'iyah dalam melestarikan batik sebagai identitas budaya komunitasnya. Identitas budaya merupakan hal yang penting dalam era global seperti saat ini. Tanpa identitas budaya orang akan mengalami kekacauan akan jati dirinya. Seperti dikatakan Phinney dalam Samovar \& Porter (2007b), tujuan utama seseorang pada masa remajanya adalah menemukan identitasnya. Jika mereka gagal menemukan identitas (budayanya), maka akan mengalami kebingungan, karena tidak memahami siapa diri mereka dan apa peran mereka dalam kehidupan. Karena itu penelitian mengenai upaya komunitas Rifa'iyah dalam pelestarian batik sebagai identitas budaya komunitasnya menjadi penting dilakukan .

Melalui penelitian ini penulis turut berkontribusi untuk memperkaya teori identitas budaya, terutama ketika diaplikasikan untuk meneliti tentang batik sebagai identitas budaya suatu komunitas. Secara metodologis penelitian ini berkontribusi untuk memperluas penggunaan metode fenomenologi dalam penelitian mengenai identitas budaya. Secara praktis penelitian ini diharapkan dapat memberi masukan bagi para pembatik Rifa'iyah Kalipucang Wetan, Batang, Jawa Tengah agar lebih memahami batik sebagai identitas budaya mereka dan kemudian mereka memiliki strategi yang tepat untuk mempertahankan batik sebagai identitas komunitasnya.

\section{LANDASAN KONSEP}

Menurut Standar Nasional Indonesia (SNI) 0239:2014 batik adalah kerajinan tangan sebagai hasil pewarnaan secara perintangan menggunakan malam (lilin) batik panas sebagai perintang warna dengan alat utama pelekat lilin batik berupa canting tulis dan/atau canting cap untuk membentuk motif tertentu yang mempunyai makna (Nugroho, 2016).

Wronska-Friend menyatakan bahwa batik merupakan metode menghias kain dengan motif yang digambar dengan malam, baik ditulis dengan canting maupun dibuat dengan cap. Selain merupakan hasil kerja artistik batik juga mengandung nilai luhur karena penuh dengan arti simbolik yang kompleks sebagai ungkapan visual dari filosofi dan pandangan orang Jawa mengenai dunia. Dibandingkan dengan jenis kain lainnya, batik memiliki karakteristik tersendiri. Pembuatannya melalui proses teknik aplikasi malam (lilin) dan teknologi 
pewarnaan yang telah berabad-abad memanfaatkan bahan dari tanaman dan dikembangkan oleh pakar (Jawa) dari generasi ke generasi. Ikonografi batik merupakan perpaduan harmonis antara motif lokal dan penyesuaian dari berbagai budaya lain. Batik juga memiliki makna berdasarkan bahasa visual dari motif dan warna-warni yang digunakan untuk mengungkapkan identitas dan kedudukan sosial seseorang. Selain dipakai sebagai busana tradisional, kini batik juga digunakan sebagai adibusana modern. Karena itu batik menjadi komoditas yang penting dan produk komersial yang dapat menghidupi masyarakat (WronskaFriend, 2016).

Batik Rifa'iyah merupakan batik dengan motif khusus yang hanya dibuat oleh para pengrajin batik komunitas Rifa'iyah di Desa Kalipucang Wetan, Batang. Sekalipun demikian, jika ditanyakan sejak kapan muncul batik di lingkungan jamaah Rifa'iyah Kalipucang Wetan, hampir tidak ada yang mengetahui secara pasti. Batik ini memiliki pengaruh Islam yang sangat kental. Awalnya, batik ini dibuat untuk memenuhi kebutuhan sandang komunitas Rifa'iyah. Namun dalam perkembangannya batik bisa membantu peningkatan perekonomian rumah tangga. Dari semua komunitas Rifa'iyah yang tersebar di hampir seluruh tanah air, hanya komunitas Rifa'iyah Kalipucang yang membuat batik. Karena itu, selain untuk dipakai sendiri, batik yang dihasilkan diedarkan ke komunitas Rifa'iyah di berbagai tempat.

Selama ini keberadaan batik Batang terlebih batik Rifa'iyah "tertutup" oleh kepopuleran batik Pekalongan yang lebih dikenal luas oleh masyarakat. Hal ini dapat dipahami karena dulu berdasarkan Lembaran Negara (Staatblad) No. 632, 31 Desember 1935 Batang merupakan bagian dari Kabupaten Pekalongan. Namun terhitung 8 April 1966 Batang menjadi kabupaten tersendiri (Pemkab Batang, 2018). Sejak itulah Batang mulai berkembang, tidak terkecuali bidang pembatikannya. Para pengusaha batik dan perajinnya segera berbenah diri.

Bagi komunitas Rifa'iyah, batik selain penutup aurat dan karya seni juga merupakan identitas budaya. Dulu hanya para anggota komunitas Rifa'iyah yang mengenakan batik Rifa'iyah. Identitas merupakan suatu hasil konstruksi di dalam suatu kelompok. Seperti dikatakan Ting Toomey dalam Samovar \& Porter (2007b) individu-individu memperoleh dan mengembangkan identitas mereka melalui interaksi dengan orang lain dalam kelompok budaya mereka. Karena itu identitas merupakan proses sosialisasi keluarga dan budaya, pengeksposan kepada budaya lain dan perkembangan pribadi. Terpaan awal identitas berasal dari keluarga tempat seseorang mulai belajar secara budaya tentang kepercayaan, nilai-nilai, dan peranperan sosial. Sejak anak berusia dini keluarga sudah mengajarkan bagaimana anak-anak bertingkah laku yang benar.

Identitas budaya ini bagi seorang individu sangat penting, terlebih dalam era globalisasi seperti saat ini. Hecht dalam Littlejohn (2005) membentuk ketiga konteks budaya, yakni meliputi individu, komunal, dan publik. Ia memperkenalkan dimensidimensi identitas khusus, termasuk perasaan (afektif), pemikiran (kognitif), dan perilaku (behavioral). Dalam interaksi antar manusia, orang memperoleh penilaian dan reaksi dari orang lain. Sebaliknya, orang memperlihatkan identitasnya dengan cara mengekspresikan diri dan merespons orang lain. Perasaan seseorang akan identitasnya merupakan dimensi subjektif (subjective dimension), sedangkan apa yang dikatakan orang lain terhadap seseorang mengenai identitasnya disebut dimensi asal (ascribed dimension). Ini artinya, rasa identitas terdiri atas maknamakna yang dipelajari dan yang diperoleh dari orang lain.

Dari perspektif teori, Phinney dalam Samovar \& Porter (2007b) menawarkan model tiga tahap untuk memahami perkembangan identitas. Meskipun model ini berfokus pada identitas etnik, namun model ini dapat juga digunakan untuk diterapkan pada identitas budaya. Pada tahap awal orang tidak terlampau peduli pada identitas budayanya. Bagi kelompok minoritas hal ini bisa jadi disebabkan keinginannya untuk memendam identitas budayanya. Pada tahap kedua orang mulai tertarik mempelajari dan memahami identitas budaya kelompok 
etniknya. Banyak faktor yang mendorong munculnya tahap ini. Tahap terakhir adalah ketika orang telah sampai pada pencapaian etnik (ethnic achievement). Pada saat ini orang telah memahami identitas budayanya. Bagi kelompok minoritas pencapaian ini ditandai dengan kemampuan mereka dalam menghadapi perlakuan diskriminatif oleh kelompok mayoritas.

Identitas budaya agar tetap melekat perlu terus dilestarikan. Sesuatu yang dilestarikan biasanya adalah hal yang dianggap berharga dan merupakan warisan atau peninggalan dari leluhur, baik yang berwujud benda (artefak) maupun non benda, seperti nilai-nilai, adat-istiadat, atau ajaran. Seiring dengan perkembangan zaman, maka banyak hal yang berubah, tidak terkecuali peninggalan leluhur, seperti batik. Salah satu tujuan pelestarian adalah untuk mempertahankan apa yang sudah ada agar tidak tergerus zaman.

Untuk melestarikan identitas budaya dapat dilakukan antara lain dengan melakukan sosialisasi. Sosialisasi mengenai kepercayaan, nilai-nilai, sikap, dan normanorma yang paling utama dan pertama dilakukan adalah di lingkungan keluarga. Seperti dikatakan Ting-Toomey dalam Samovar \& Porter (2007b) bahwa individu memperoleh dan mengembangkan identitasnya melalui interaksi dengan orang lain dalam kelompok budayanya. Karena itu, perkembangan identitas merupakan proses sosialisasi keluarga dan budaya, penerpaan pada budaya lain, dan perkembangan pribadi. Identitas budaya yang terbentuk dalam kehidupan seorang individu akan memengaruhi persepsi diri setiap anggota kelompok.

Menurut Charles Colton dalam Samovar \& Porter (2007b), keluarga merupakan unit dasar dari suatu negara. Keluarga merupakan satu dari institusi sosial budaya yang memiliki tugas menyampaikan budaya dari satu generasi ke generasi berikutnya. Individu, keluarga, dan budaya bekerja bersama untuk mengajarkan tentang "esensi" budaya. Keluarga merupakan kelompok sosial paling menentukan dalam suatu komunitas, karena keluargalah yang mempersiapkan para anggotanya untuk berbagai peran yang akan dilakukan dalam masyarakat. Dengan kata lain, baik buruknya suatu masyarakat tergantung pada para orang tua di dalam mendidik dan mengasuh anakanaknya untuk berbicara dan bersikap yang baik.

\section{METODE PENELITIAN}

Penelitian ini menggunakan paradigma konstruktivisme. Paradigma konstruktivisme menurut Schwandt dalam Denzin \& Lincoln (1994), berpegang pada pandangan bahwa apa yang dipahami sebagai pengetahuan dan kebenaran objektif merupakan hasil perspektif. Pengetahuan dan kebenaran merupakan ciptaan dan tidak ditemukan oleh pikiran. Realitas dapat diungkapkan dalam beragam sistem simbol dan bahasa. Pendekatan penelitian adalah kualitatif, yaitu penelitian yang menggambarkan atau mendeskripsikan suatu masalah yang hasilnya dapat tidak digeneralisasikan (Kriyantono, 2008). Sedangkan jenis penelitiannya adalah penelitian deskriptif.

Metode penelitian yang digunakan adalah fenomenologi. Fenomenologi adalah salah satu dari banyak jenis metode penelitian kualitatif yang digunakan untuk meneliti pengalaman hidup manusia. Peneliti fenomenologi mengharapkan untuk mendapat pemahaman tentang "kebenaran" yang esensial dari pengalaman hidup (Sobur, 2013). Fenomenologi mengasumsikan bahwa pengetahuan dapat diperoleh dengan berkonsentrasi pada fenomena yang dialami orang-orang.

Menurut Littlejohn dan Foss dalam Littlejohn (2005), fenomenologi adalah suatu tradisi untuk mengeksplorasi pengalaman manusia. Merieau-Ponty dalam Littlejohn (2005) teoretisi tradisi ini mengatakan bahwa semua pengetahuannya tentang dunia, bahkan pengetahuan ilmiahnya, didapat dari sudut pandangnya sendiri atau dari pengalamannya tentang dunia. Jadi, fenomenologi menggambarkan langsung pengalamanpengalaman sebagaimana cara manusia memahami dunia. Sedangkan Griffin (2003) mengatakan bahwa dalam fenomenologi orang menganalisis kehidupan sehari-hari dari 
sudut pandang orang yang hidup dalam kehidupannya sendiri.

Untuk memperoleh data, peneliti melakukan pengamatan lapangan, wawancara mendalam, dan studi dokumentasi. Peneliti memperoleh data dari para informan. Informan kunci penelitian ini adalah Penasihat Paguyuban Pembatik Rifa'iyah, Miftakhutin (39). Informan tambahan terdiri atas: peneliti batik William Kwan Hwie Liong (63), pembatik tertua, Umriah (78), Siti Alkhomah (27), pembatik muda Nurul Mashlalah (16), dan Ketua Jamiah Rifa'iyah Batang, K.H. Ali Nahri (63).

Teknik analisis data dilakukan dengan teknik pengembangan sistem koding. Kunci yang digunakan untuk mengembangkan sistem koding adalah dengan membuat daftar kata yang akan dikonseptualisasikan ke dalam kategori dan dihubungkan dengan general framework. Penelitian ini dilakukan selama enam bulan, mulai dari Januari-Juli 2017.

\section{HASIL PENELITIAN DAN PEMBAHASAN}

Lokasi penelitian ini adalah Desa Kalipucang Wetan, Batang, Jawa Tengah. Batang terletak di pesisir utara Jawa Tengah. Luas daerahnya sekira 78.864, 16 hektar. Dari Pekalongan yang dikenal sebagai kota batik, Batang hanya berjarak sembilan kilometer. Semula Batang menjadi satu dengan Pekalongan, namun sejak 1966 Batang berdiri sendiri sebagai kota kabupaten. Menurut catatan sejarah Batang, Batang dua kali berstatus sebagai kabupaten. Periode I berawal pada saat penjajahan Belanda, kirakira dari awal abad 17 sampai dengan 31 Desember 1935. Sedang periode II, dimulai pada awal kebangkitan Orde Baru (8 April 1966) sampai sekarang.

Sebagian besar warga Kalipucang Wetan adalah anggota jamaah Rifa'iyah. Jamaah atau komunitas Rifa'iyah merupakan jamaah tarekat yang mengikuti pemikiran Syeh K.H. Ahmad Rifa'i yang lahir di Kendal pada 1786. Sejak muda Kiai Rifa'i sangat gigih melawan pemerintah penjajahan Belanda. Kiai karismatik ini mengajak masyarakat untuk melawan pemerintah
Belanda dengan menolak membayar pajak yang ditetapkan Belanda. Karena itu Belanda selalu mengawasi gerak-geriknya dan beberapa kali mengirimnya ke rumah tahanan. Bahkan akhirnya Belanda membuangnya ke Ambon dan kemudian ke Manado.

Pasca penangkapan Kiai Rifa'i, salah satu santrinya yang bernama Kiai Ilham pulang ke kampungnya di Desa Kalipucang, Batang. Di desa yang mayoritas penduduknya petani ini ia meneruskan dakwah Kiai Rifa'i. Ia pun mengajarkan kepada kaum perempuan di sana yang memiliki kegiatan membatik agar tidak menggambar makhluk yang bernyawa. Karena itu batik yang oleh masyarakat di luar komunitas Rifa'iyah disebut batik Rifa'iyah tidak ada yang bermotif makhluk bernyawa. Kalau pun ada gambar hewan, maka tidak digambar secara utuh, melainkan hanya kepala, sayap, atau ekornya. Bagian tubuh yang tidak tampak diganti dengan ranting atau bunga.

Menurut Miftakhutin, saat ini para pembatik mengenal sekitar 24 motif batik Rifa'iyah. Namun mereka tidak semuanya mengetahui makna filosofinya. Motif-motif tersebut terdiri atas: pelo ati, kotak kitir, banji, sigar kupat, lancur, tambal, kawung ndog, kawung jenggot, dlorong, materos satrio, ila ili, gemblong sairis, dapel, nyah pratin, romo gendong, jeruk no'i, keongan, krokotan, liris, klasem, kluwungan, jamblang, gendaghan dan wagean. Motif yang paling dikenal dan mencirikan batik Rifa'iyah adalah batik pelo ati (hati dan ampela ayam).

Menurut K.H. Ali Nahri (hasil wawancara pada 12 Mei 2017 di Batang), motif pelo ati menggambarkan ajaran sufisme dari Kiai Rifa'i yang tersurat dalam kitab Tarujumah (Asnal Miqashad 11:407) karangan Kiai Rifa'i. Di dalam hati manusia terdapat delapan sifat kebaikan, yaitu zuhud (tidak mementingkan keduniawian), qana'at (merasa cukup atas karunia-Nya), shabar (sabar), tawakal (berserah diri kepada-Nya), mujahadah (bersungguh-sungguh), ridla (rela), syukur, dan ikhlas. Semua sifat ini mengandung makna kahauf (takut), mahabbah (rasa cinta), dan makrifat (perenungan kepada Allah). Sebaliknya, ampela menggambarkan tempat kotoran yang 
melambangkan sifat-sifat buruk manusia, yaitu hubbu al-dunya (mencintai dunia secara berlebihan), thama' (rakus), itba' al-hawa (mengikuti hawa nafsu), 'ujub (suka mengagumi diri sendiri), riya (suka dipuji), takabur (sombong), hasad (dengki) dan sum'ah (suka membicarakan amal kebajikannya pada orang).

Peneliti batik Batang, William Kwan Hwie Liong (hasil wawancara pada 4 Januari 2017 di Jakarta), membenarkan masih minimnya pemahaman pengrajin batik terhadap makna motif batik. "Meskipun mereka membatik secara turun-temurun, tetapi kalau pendahulunya tidak menjelaskan makna motif batiknya, tentu para penerusnya tidak tahu. Bahkan ada motif-motif batik Rifa'iyah yang sudah tidak dibuat lagi oleh pembatik generasi sekarang karena terlalu rumit," ungkap William.

Menurut William, desain batik Rifa'iyah termasuk desain klasik. Salah satu motifnya, yaitu motif gringsing, sudah ada sejak zaman kerajaan Hindu dan Buddha sekira abad VII di Jawa. Pada waktu masyarakat di Dukuh Balaikambang, Kecamatan Gringsing, Kabupaten Batang menemukan arca Sri Vasudara, mereka menyaksikan arca tersebut mengenakan sinjang (kain) bermotif gringsing atau bergambar sisik ikan, seperti pada motif batik Rifa'iyah. "Batik Rifa'iyah ini istimewa. Saat wilayah lain mulai meninggalkan desain klasik, perajin batik Rifa'iyah di Kalipucang tetap setia mempertahankannya. Batik yang bermotif islami ini justru muncul di Batang, bukan di Pekalongan. Padahal di sana para juragan batiknya terkenal sebagai pemeluk Islam yang taat," kata William.

Sebagian penduduk Desa Kalipucang Wetan yang mengidentifikasi diri sebagai anggota komunitas Rifa'iyah memandang batik Rifa'iyah sebagai identitas budaya mereka. Dalam kehidupan sehari-hari, mereka baik laki-laki maupun perempuan, menggunakan batik sebagai penutup aurat. Kaum perempuan Rifa'iyah umumnya membatik sendiri kain yang dikenakan seharihari. Mereka membatik selembar kain selama kurang lebih tiga bulan. Bahkan jika motifnya rumit bisa memakan waktu enam bulan hingga satu tahun. Lamanya proses pembuatan batik ini karena kain dibatik pada kedua sisinya (bolak-balik). Hingga sekarang kaum perempuan Rifa'iyah masih terus membatik, baik untuk digunakan sendiri maupun untuk dijual kepada para peminat batik tradisional.

Seperti yang dikatakan oleh Ting Toomey dalam Darmastuti (2013) bahwa identitas budaya merupakan perasaan (emotional significance) dari seseorang untuk ikut memiliki (sense of belonging) atau berafiliasi dengan kultur tertentu. Masyarakat yang terbagi ke dalam kelompok-kelompok kemudian melakukan identifikasi kultural. Artinya, masing-masing orang mempertimbangkan diri mereka sebagai perwakilan dari sebuah budaya partikular. Identifikasi ini akan menentukan apakah seseorang termasuk dalam kelompok dalam (in-group) atau kelompok luar (out-group). Demikian halnya dengan penduduk Kalipucang Wetan. Sebagian dari mereka mengidentifikasi diri sebagai anggota komunitas Rifa'iyah. Karena itu mereka dalam kehidupan sehari-hari mengikuti nilainilai yang dianut kaum Rifa 'iyah.

Sejak Bupati Batang periode 20132017, Yoyok Riyo Sudibyo menjabat, batik Rifa'iyah mulai mendapat perhatian. Bupati termasuk tokoh yang sangat bersemangat memperkenalkan batik Batang, termasuk batik Rifa'iyah, sebagai warisan budaya leluhur. Karena itu, pada waktu Kabupaten Batang berulang tahun, Yoyok mengajak pembatik Rifa'iyah ikut berpameran. Sejak itulah orang-orang mulai mengenal batik Rifa'iyah. "Meskipun sesama orang Batang, ternyata ada yang belum tahu ada batik Rifa'iyah," tutur Miftakhutin yang sangat giat memperkenalkan batik Rifa'iyah.

Pada kesempatan lain, Batang Heritage juga mengadakan acara "Merayakan Batik Rifa'iyah". Acara ini secara khusus mempromosikan batik Rifa 'iyah sebagai batik warisan masyarakat Batang. William yang berasal dari Batang juga termasuk orang yang giat mengajak para pembatik Rifa'iyah mengikuti pameran batik di luar Batang. Mula-mula ia menggandeng pengrajin untuk berpameran di International Handicraft (Inacraft) di Jakarta Convention Center, Jakarta. Setelah itu ia mengajak pembatik 
Rifa'iyah mengikuti berbagai pameran di Jakarta, termasuk pameran untuk memperingati Hari Batik Nasional 2 Oktober 2016 di Museum Nasional.

Badan Ekonomi Kreatif (Bekraf) juga pernah mengikutkan batik Rifa'iyah dalam Festival Green is The New Black di Singapura pada April 2017. Sebagai pegiat batik Rifa'iyah, Miftakhutin merasa gembira dengan makin banyaknya orang yang mengetahui dan menyukai batiknya. Sayangnya, ketika batik Rifa'iyah mulai dikenal dan dicari orang, jumlah pembatiknya tidak bertambah jika tidak mau dikatakan berkurang. "Pembatik muda sangat sedikit, sehingga perlu dipikirkan strategi pengaderannya," tutur Miftakhutin.

Pada zaman dulu, semua anak perempuan sejak kecil belajar membatik. "Mulanya ikut-ikutan Mak saya. Kalau Mak membatik saya duduk di dekatnya sambil memegang canting terus menyiduk malam dan menggoreskannya di kain mori yang sengaja disediakan Mak. Seperti main-main saja, tapi lama-lama jadi mahir," ujar Miftakhutin. Sambil membatik, ia juga menghafalkan syi'iran, syair berisikan ajaran agama Islam yang digubah Syekh Rifa'i ke dalam bahasa Jawa.

Salah satu syair yang dihafal ibu satu anak ini sejak kecil adalah pepenget (peringatan) bahwa hidup ini sangat singkat. "Wong urip ning ndonyo mung sedela, isih suwe mbesuk ning alam baqa. Elingo pati den bisa semaya. Elingo den cabut nyowo nira. Larane ngungkuli wong den kunjoro. (Orang hidup di dunia hanya sebentar, lebih lama kelak di alam baka. Ingatlah bahwa kematian pasti akan datang dan tidak bisa dijanjikan. Ingatlah ketika nyawa kita dicabut. Sakitnya sungguh luar biasa, pen.)," Miftakhutin menembangkan sepenggal syair sambil menggoreskan cantingnya ke kain.

Menurut lulusan IAIN Pekalongan ini, di Batang kala itu belum banyak orang yang memiliki televisi, apalagi alat komunikasi, seperti telepon genggam. Karena itu bagi anak-anak membatik bisa menjadi hiburan.

Mak Umriyah yang biasa dipanggil Si Um, juga mengaku belajar membatik sejak kecil. "Awalnya ikut-ikut orang tua saja. Dulu kan anak perempuan tidak boleh ke mana- mana. Jadi, mbatik saja di rumah. Karena sudah biasa mbatik jadi keterusan sampai sekarang," tutur ibu dari enam anak ini. Mak Si Um termasuk pembatik senior yang kreatif. Ia tidak selalu membatik motif batik Rifa'iyah.

Ia bisa membuat motif apa saja yang ada di benaknya. Misalnya, motif jamur atau daun sirih. Biasanya ia membatik langsung tanpa harus ada polanya. Ketika William memintanya untuk mengingat-ingat motif batik yang dulu pernah dibuatnya, ia pun berhasil mereka-reka motif jeruk no' $i$. "Motif ini sudah lama tidak dibuat orang. Tapi setelah saya coba ingat-ingat, akhirnya saya bisa menemukan motif jeruk no' $i$," ujar Mak Si Um lega.

Seperti halnya gadis cilik lain di Kalipucang, Siti Alkhomah sejak kecil sudah mengenal canting. "Dulu saya belajar membatik khusus motif-motif Rifa'iyah, seperti halnya ibu dan orang-orang dewasa di rumah. Kata ibu saya, batik yang kami buat tidak sama dengan batik lain (yang ada di luar komunitas)," jelas Siti yang pernah menjadi TKW di Singapura selama tiga tahun. Ibu satu anak ini pun terus membatik hingga sekarang. Pengalaman hidupnya di mancanegara mendorongnya untuk membuat motif-motif kontemporer. "Kalau hanya membatik motif Rifa'iyah, pangsa pasarnya terbatas. Karena itu saya coba membuat motif kontemporer untuk mencari peluang pasar," tutur Siti yang karya batiknya dibeli oleh desainer Winny Nagawati dan Kenny Kho, serta William ini.

Menurut Miftakhutin, "Biasanya pembatik itu mewarisi bakat ibunya. Kalau ibunya bisa menghasilkan batik yang halus, batikan anak-anaknya juga halus. Di sini ada sekitar 10 orang pembatik halus. Sayang satu orang mengundurkan diri, tidak mau membatik lagi," jelas Miftakhutin yang tergolong pembatik premium.

Seperti dikemukakan oleh Ting Toomey dalam Samovar \& Porter (2007b), bahwa identitas merupakan suatu hasil konstruksi di dalam suatu kelompok. Para individu dalam kelompok budaya tersebut saling berinteraksi. Melalui interaksi inilah mereka mengembangkan identitasnya. Identitas ini kemudian ditampilkan ke luar 
lingkungan. Karena itu identitas selain merupakan proses sosialisasi kepada keluarga, juga merupakan pengeksposan kepada lingkungan luar.

Anak-anak di lingkungan Rifa'iyah sejak kecil bergaul dan berinteraksi dengan sesama anggota komunitas. Mereka tersosialisasikan dengan nilai-nilai dan kepercayaan-kepercayaan, serta ritual-ritual yang diyakini oleh komunitas Rifa'iyah. Nilai merupakan konsepsi yang dihayati seseorang mengenai apa yang paling penting dan kurang penting, apa yang paling baik dan kurang baik, dan apa yang lebih benar dan kurang benar. Nilai yang dianut oleh komunitas Rifa'iyah adalah bahwa kehidupan di akhirat lebih baik daripada kehidupan di dunia. Karena itu selama berada di dunia manusia harus mencari bekal untuk kehidupan akhiratnya yang lebih abadi.

Adapun kepercayaan adalah keyakinan yang dianut oleh seseorang. Keyakinan ini sering kali dihubungkan dengan agama, sehingga menjadi kepercayaan agama. Dalam hal ini komunitas Rifa'iyah memiliki kepercayaan (agama) Islam yang diajarkan oleh Nabi Muhammad saw. Kepercayaan ini tampak dalam kehidupan sehari-hari para penganutnya. Misalnya, ketika mereka menjalankan salat wajib berjamaah lima waktu di musala yang diikuti dengan zikir (memuji Allah Swt.) dan membaca Al Quran.

Seluruh nilai, kepercayaan, dan ritual ini diinternalisasikan kepada para anggota komunitas Rifa'iyah sejak mereka kanakkanak. Setiap Subuh para orang tua dan anakanak memenuhi musala untuk melakukan salat berjamaah. Seusai salat dan mengaji barulah mereka kembali ke rumah masingmasing. Semua kegiatan ini menjadi ciri yang dimiliki oleh keluarga komunitas Rifa 'iyah.

Pada zaman dulu semua anggota komunitas Rifa'iyah pergi ke musala dengan mengenakan kain dan sarung batik. Kaum perempuan mengenakan kain panjang, sedangkan kaum laki-laki mengenakan kain sarung. Kain yang mereka kenakan haruslah dibuat yang sesuai dengan kaidah Islam, yakni tidak menggambarkan makhluk bernyawa. Mereka meyakini jika mengenakan kain yang bermotif makhluk bernyawa, salatnya tidak sah dan tidak diterima Allah.
Kini zaman sudah berkembang. "Anakanak perempuan sekarang tidak ada yang jarikan (mengenakan kain batik). Laki-laki juga tidak lagi sarungan, kecuali ketika salat. Karena itu, tidak ada kebutuhan mereka terhadap batik," kata Miftakhutin. Akibatnya, kegiatan membatik tidak lagi menjadi suatu hal yang menarik dan urgen. Malah mereka menganggap membatik itu tidak produktif. Sudah membuatnya lama, hasilnya tidak bisa cepat dinikmati. Selain itu, lanjut Miftakhutin, munculnya televisi dan telepon pintar menjadi faktor penyebab kaum remaja meninggalkan kegiatan membatik. Mereka lebih memilih mengisi waktu luang dan mencari hiburan dengan menonton televisi atau bermain gadget daripada membatik. Ditambah lagi sekarang, semakin banyak pabrik bertumbuh di sekitar Batang. Hal ini mendorong para remaja putri lebih tertarik menjadi buruh pabrik daripada membatik. Dengan menjadi buruh, setiap Kamis mereka mendapat uang," tutur Miftakhutin seraya menghela napas.

Meskipun menghadapi situasi yang kurang menggembirakan, Miftakhutin tidak tinggal diam. Perempuan yang merupakan motornya pengrajin batik Rifa'iyah ini tanpa kenal lelah berusaha menyadarkan kaum perempuan muda agar terus mencintai batik. Perjumpaannya dengan komunitas pembatik lain dalam pameran-pameran banyak memotivasi dan menginspirasinya. Ia mencoba memperluas jaringan demi meningkatkan penjualan batik Rifa'iyah. Atas dorongan Dinas Perdagangan dia mendirikan Kelompok Usaha Bersama (KUB) Batik pada 2011, William ditunjuk sebagai pendampingnya. Para anggota KUB dapat meminjam uang yang dikumpulkan dari keuntungan menjual batik untuk membeli mori dan obat batik. "Melalui KUB pemerintah berharap agar para pengrajin bisa terus berkarya tanpa terkendala bahan baku. Namun praktiknya sulit. Ada saja anggota yang meminjam uang tapi untuk beli keperluan pribadi, bukan untuk membeli bahan baku batik. Malah sudah empat tahun lebih uangnya tidak dikembalikan," jelas Miftakhutin tentang kendala yang dihadapi KUB. 
Keberadaan KUB ini mengalami pasang surut. Anggotanya yang semula 20 orang susut menjadi 11 orang. Padahal dengan adanya KUB Miftakhutin berharap batik karya para pengrajin bisa dibuatkan klasifikasi dan standarisasi harganya. "Standarisasi batik itu penting. Kalau tidak ada standarnya, kasihan pembeli. Mereka bisa mendapat batik halus dengan harga yang sesuai. Bisa juga mendapat batik kualitas rendah namun dengan harga mahal. Ini yang harus dihindari." tutur Miftakhutin seraya menjelaskan klasifikasi batik, yaitu halus, sedang, dan kasar.

Dengan standarisasi harga batik bisa sesuai dengan klasifikasinya. "Selama ini para pembatik menghargai karyanya sesuka hati. Mereka suka mematok harga batiknya terlalu tinggi padahal kualitasnya kurang bagus. Kalau diingatkan, dia malah mengatakan, 'Orangnya beli mau kok.' Dia tidak tahu bahwa cara seperti ini bisa mengecewakan pembeli dan setelah itu mereka tidak mau beli lagi. Bahkan mungkin mereka akan bercerita tentang pengalamannya ini pada kawan-kawannya."

Kendala lain yang dirasakan adalah belum adanya galeri tempat memamerkan batik. Keberadaan galeri ini sangat penting mengingat kampung ini merupakan sentra batik Rifa'iyah. Apalagi belakangan ini mulai berdatangan turis-turis lokal yang ingin melihat perkampungan batik Rifa'iyah. Dengan adanya pembeli dari luar, seharusnya mulai dipikirkan logo dan kemasan produknya. "Di sini batik bagus dan mahal masih dibawa dengan tas keresek, sehingga tidak membuat yang membeli bangga. Beda dengan di tempat lain, batik sudah dikemas dalam tas kertas yang didesain bagus," ujar Miftakhutin yang sudah menyediakan tas kertas untuk mewadahi batiknya.

Kendala lain yang dihadapi Kelompok Pembatik Rifa'iyah adalah masih banyaknya anggapan para pembatik bahwa membatik merupakan kegiatan selingan. Pekerjaan utama mereka adalah petani. Mereka tidak pernah menargetkan harus bisa menyelesaikan berapa lembar batik dalam sebulan. Begitu musim tanam padi atau panen, semua orang turun ke sawah. Membatik betul-betul mereka tinggalkan. Tak ingin seperti kebanyakan pembatik lain, Miftakhutin bersama dua adiknya selalu menargetkan membuat selembar batik setiap bulannya. "Saya berusaha keras agar bisa terus membatik. Nanti kalau banyak yang berminat beli batik kami, tapi stoknya kosong bagaimana?" tutur perempuan yang sangat energik ini.

Untuk menghadapi berbagai kendala di atas, beberapa usaha sudah dilakukan oleh Paguyuban Batik Rifa'iyah. Sebagai pembina paguyuban Miftakhutin berusaha sekuat tenaga untuk melestarikan batik Rifa'iyah dengan berbagai cara. Ia mencoba membuka kelas membatik secara gratis untuk muridmuridnya yang duduk di kelas III SD. Di rumahnya, setiap Minggu ia juga mengajar membatik secara cuma-cuma kepada anakanak yang berminat. "Biarpun gratis sedikit yang mau ikut. Awalnya ada 10 anak, lamalama tinggal empat anak. Anak-anak yang lain lebih suka menonton televisi atau jalanjalan. Ini sangat memprihatinkan," keluh Miftakhutin yang merelakan ruang tamu di rumahnya untuk belajar membatik.

Di KUB meskipun anggotanya berkurang, Miftakhutin terus berusaha agar koperasi ini tetap berjalan. Sebulan sekali ia mengumpulkan para anggotanya untuk berdiskusi tentang batik dan komunitas Rifa'iyah. Hal ini dimaksudkan untuk memelihara ingatan mereka tentang batik dan kebiasaan-kebiasaan mereka pada zaman dulu. Ia pun mengajak mereka memikirkan motif batik kreasi baru agar ada pembaruan. "Dulu kami pernah membatik bersama di atas selembar mori biar cepat selesai. Ternyata tidak efektif, karena setiap orang memiliki goresan sendiri. Apalagi kalau cantingnya tidak sama, hasilnya jadi kurang rapi," ujar Miftakhutin.

Dua tahun lalu, Bekraf membangun ekosistem desa kreatif batik di Batang. Hal ini dimaksudkan untuk menggelorakan semangat membatik para pengrajin. Untuk itu selama tiga bulan, terhitung mulai September hingga November 2016 Bekraf mengadakan pelatihan setiap bulan selama empat hari. Pelatihan terakhir diberikan pada 1-4 November 2016. Direktur Fasilitasi Infrastruktur Fisik Bekraf, Selliane Halia Ishak menjelaskan, Batang terpilih sebagai 
desa kreatif karena di sini terdapat desain batik yang khas dan tidak dimiliki oleh daerah lain, yaitu batik tiga negeri dan batik Rifa'iyah. Khusus batik Rifa'iyah pengrajinnya hampir tidak ada regenerasi. Pembatik muda hanya ada enam orang, sehingga dikhawatirkan akan punah (Anon, 2016).

Dalam pelatihan selama empat hari ini para pembatik mendapat pembekalan mengenai teknik pewarnaan alami dan buatan, desain batik kontemporer serta paduan antara kontemporer dan klasik. Juga untuk menyadarkan pembatik tentang potensi ekonomi yang dapat dikembangkan dari batik. "Pada pelatihan yang diikuti 40 pengrajin ini kami ingin memotivasi peserta pelatihan untuk melestarikan dan mengembangkan desain batik Rifa'iyah. Batik memiliki potensi ekonomi yang besar," jelas Selliane yang sebelumnya memilih Maumere, Kabupaten Sikka untuk mengembangkan seni tenun.

Menurut Miftakhutin, saat pelatihan mentor meminta setiap pengrajin menyelesaikan selembar batik dalam waktu sebulan, namun hampir semua pembatik tidak ada yang sanggup memenuhi. "Alasannya, sibuk mengurus anak atau sibuk ke sawah. Begitulah, tidak mudah mengajak pembatik menjadi produktif," kata Miftakhutin yang tetap bersemangat memajukan batik Rifa'iyah.

Sebagaimana dikatakan Phinney dalam Samovar \& Porter (2007b), batik menawarkan model tiga tahap untuk memahami perkembangan identitas. Meskipun model ini berfokus pada identitas etnik, namun model ini dapat juga digunakan untuk diterapkan pada identitas budaya. Pada tahap awal orang tidak terlampau peduli pada identitas budayanya. Sama seperti halnya komunitas Rifa'iyah, mereka awalnya tidak terlalu memahami makna identitas budaya mereka. Mereka memahami bahwa batik selalu menjadi pilihan busana sehari-hari. "Kalau ditanyakan, apa makna motif batiknya, banyak pengrajin batik yang tidak tahu,"William.

Bagi kelompok minoritas, seperti komunitas Rifa'iyah hal ini bisa jadi disebabkan keinginan pimpinannya untuk memendam identitas budayanya. Namun demikian, pada tahap kedua orang mulai tertarik mempelajari dan memahami identitas budaya kelompok etniknya. Banyak faktor yang mendorong munculnya tahap ini. Salah satunya adalah situasi politik yang sudah berubah, sehingga sebagai kaum minoritas mereka sudah tidak terlalu mengalami pembedaan lagi dari kelompok lainnya. Hal ini terjadi setelah pengangkatan Kiai Rifa'i sebagai pahlawan nasional pada 2004. Sejak itu sikap masyarakat terhadap komunitas Rifa'iyah mulai berubah. Mereka tidak lagi menganggap komunitas Rifa'iyah sebagai penganut Islam yang berbeda.

Tahap terakhir adalah ketika orang telah sampai pada pencapaian etnik (ethnic achievement). Pada saat ini orang telah memahami identitas budayanya. Bagi kelompok minoritas pencapaian ini ditandai dengan kemampuan mereka menghadapi perlakuan diskriminatif dari kelompok mayoritas. Martin dan Nakayama dalam Samovar \& Porter (2007b), membagi tahapan ini menjadi empat: unexamined identity, conformity (penerimaan), resistance and separatism, dan integration. Pada tahap awal, identitas yang tidak disadari sama seperti tahap awal model Penny. Pada awalnya kaum muda Rifa'iyah belum terlalu menyadari identitas budaya mereka. Kendati demikian melalui internalisasi nilai-nilai Islam dan adat istiadatnya yang senantiasa ditanamkan para orang tua, generasi muda Rifa'iyah telah menerima nilai-nilai tersebut.

Ketika identitas ini diekspresikan keluar, tidak semua pihak menerima. Ada yang menolak (resistan). Namun dengan semakin menguatnya identitas budaya komunitas Rifa 'iyah, terdapat anggota budaya dominan yang mulai lebih menyadari adanya ketidaksetaraan sosial ini. Mereka pun mulai mendekati kelompok minoritas, sehingga mulai muncul upaya-upaya pemahaman terhadap kelompok minoritas. Pada tahap ini mulailah terjadi penyatuan (integrasi) yang membangun pemahaman dan apresiasi terhadap identitas budaya komunitas minoritas. Hal ini ditandai dengan mulai terbukanya komunitas Rifa'iyah dengan dunia luar, melalui ajang pameran batik dan 
kunjungan-kunjungan para wisatawan dan penggemar batik ke kampung Rifa 'iyah.

\section{PENUTUP}

\section{Simpulan}

Berkurangnya minat anak perempuan Rifa'iyah membatik disebabkan oleh beberapa faktor. Dulu, anak-anak perempuan belajar membatik sejak usia delapan tahunan. Setelah dewasa mereka membuat batik untuk memenuhi kebutuhan busana sehari-hari. Seiring dengan perkembangan zaman, anak perempuan muda komunitas Rifa'iyah tidak lagi mengenakan kain batik sebagai busana sehari-hari, sehingga kebutuhan mereka terhadap batik berkurang bahkan tidak ada lagi. Minat mereka untuk membatik surut.

Perkembangan teknologi komunikasi, seperti media televisi yang menayangkan berbagai acara hiburan sangat menarik perhatian kawula muda. Demikian pula piranti gadget dan telepon pintar membuat anak-anak muda lebih asik bermain dengan kedua piranti tersebut. Jam sekolah yang panjang hingga sore hari mengurangi waktu mereka untuk melakukan kegiatan membatik. Selain itu, semakin banyaknya pabrik di sekitar Batang yang membutuhkan banyak tenaga kerja mendorong kawula muda untuk bekerja di pabrik yang lebih cepat menghasilkan uang daripada membatik.

Sebagai upaya untuk melestarikan batik didirikan Paguyuban Pembatik Rifa'iyah. Di paguyuban ini, para pembatik dapat saling bertukar pengetahuan mengenai teknik membatik, menentukan standarisasi batik, dan memperoleh informasi mengenai pembatikan di luar komunitas. Di samping itu, Miftakhutin sebagai pembina paguyuban membuka kelas membatik untuk murid SD di sekolahnya, memberikan kursus membatik gratis untuk anak-anak perempuan, bekerja sama dengan Badan Ekonomi Kreatif mengadakan pelatihan bagi para pembatik untuk meningkatkan teknik pembatikan dan pewarnaan, menciptakan desain yang lebih menarik, dan mengembangkan teknik pemasaran batik, serta mengikuti pameranpameran batik, baik di dalam maupun luar negeri.

\section{Saran}

Untuk menumbuhkan apresiasi generasi muda terhadap batik, Paguyuban Pembatik Rifa'iyah hendaknya menggandeng pihak lain, seperti desainer untuk mengadakan acara yang dapat menarik kawula muda. Misalnya, mengadakan peragaan busana batik atau membuat akun Instagram atau Facebook untuk menjelaskan filosofi dan makna-makna motif batik Rifa'iyah. Membatik hendaknya dimasukkan sebagai mata pelajaran yang bersifat muatan lokal di sekolah-sekolah di wilayah Batang. Untuk menarik minat kaum muda Rifa'iyah terhadap batik, pemerintah daerah hendaknya memberikan beasiswa kepada siswa-siswa Sekolah Menengah Kejuruan Jurusan Busana untuk mempelajari batik. Untuk meningkatkan rasa percaya diri para pembatik Rifa'iyah, pemerintah perlu membuatkan galeri batik. Di galeri ini para pembatik dapat memajang karya-karyanya sehingga dapat diapresiasi baik oleh warga setempat maupun para turis yang tertarik melihat batik Rifa'iyah. Setiap keluarga komunitas Rifa'iyah hendaknya menanamkan pemahaman tentang batik dan maknanya sejak anak-anak masih kecil. Dengan demikian anak-anak sejak kecil sudah tersosialisasi mengenai batik sebagai identitas budayanya.

\section{DAFTAR PUSTAKA}

Anon (2016) Bekraf Bangun Ekosistem Desa Kreatif untuk Batik di Batang Jawa Tengah. [Online]. 2016. Tribunnews.com. Available from:

http://www.tribunnews.com/bisnis/2016/11/ 03 [Accessed: 3 January 2017].

Astuti, S.Y. (2006) Bentuk Ragam Hias Batik Rifa"iyah Di Kalipucang Wetan, Kabupaten Batang. Surakarta, Sekolah Tinggi Seni Indonesia Surakarta.

Darmastuti, R. (2013) Mindfulness dalam Komunikasi Antarbudaya. Yogyakarta, Buku Litera.

Denzin, N.K. \& Lincoln, Y.S. (1994) Handbook of Qualitative Research. New Delhi, SAGE Publication Inc.

Geertz, C. (1992) Tafsir Kebudayaan. Yogyakarta, Kanisius.

Griffin, E.A. (2003) A First Look at 
Communication Theory. 5th edition. New York, McGraw Hill.

Gudykunst, W.B. \& Kim, Y.Y. (1999) Communicating with Strangers: An Approach to Intercultural Communication. New York, McGraw-Hill Higher Education.

Kriyantono, R. (2008) Teknik Praktis Riset Komunikasi. Jakarta, Kencana Prenada Media.

Littlejohn, S.W. (2005) Theories of Human Communication. 5th edition. BelmontCalifornia, Wadsworth Cengage Learning.

Mulyana, D. (2008) Ilmu Komunikasi: Suatu Pengantar. Bandung, Remaja Rosdakarya.

Nugroho, H. (2016) Pengertian Batik, Ciri Batik dan Tiruan Batik serta Paduan Batik. [Online]. 2016. Balai Besar Kerajinan dan Batik. Available from: https://bbkb.kemenperin.go.id/index.php/pos t/read/pengertian_batik_ciri_batik_dan_tiru an_batik_serta_paduan_batik_0 [Äccessed: 25 April 2018].

Pemkab Batang (2018) Mengenal Batang, Kilas Batang, Sejarah. [Online]. 2018. Available from:

https://www.batangkab.go.id/?p=2\&id=1 [Accessed: 25 April 2018].

Prizilla, A.B. \& Sachari, A. (2018) THE VISUAL ORNAMENTS OF THE RIFA'IYAH PELO ATI BATIK AS A MODE OF
ISLAMIC PROSELYTISM. IJASOSInternational E-journal of Advances in Social Sciences. [Online] 1104-1111. Available from: doi:10.18769/ijasos.398232.

Rahardjo, T. \& Ramadhan, M. (2005) Menghargai Perbedaan Kultural: Mindfulness dalam Komunikasi Antaretnis. Yogyakarta, Pustaka Pelajar.

Samovar, L.A. \& Porter, R.E. (2007) Communication Between Cultures. California, Wadsworth Cengage Learning.

Sobur, A. (2013) Filsafat Komunikasi, Tradisi dan Metode Fenomenologi. Bandung, Rosda Karya.

Susanti, I.E. \& Purwaningsih, S.M. (2015) LUMPIA SEMARANG PADA MASA ORDE BARU (Lumpia sebagai Identitas Budaya Etnis Tionghoa Peranakan Semarang). Avatara e-Journal Pendidikan Sejarah. [Online] 3 (3), 384-390. Available from:

http://jurnalmahasiswa.unesa.ac.id/index.ph p/avatara/article/view/12661/16415.

Wronska-Friend, M. (2016) Batik Jawa Bagi Dunia. Jakarta, Komunitas Lintas Budaya Indonesia.

Yudha, I.P.P.K. (2014) Perubahan Identitas Budaya Etnis Tionghoa di Desa Pupuan, Kecamatan Pupuan, Kabupaten Tabanan. Universitas Udayana. 